\title{
NEW MULTILEVEL APPROACH IN MEDICAL REHABILITATION
}

Petro Kolisnyk ${ }^{1,2}$, Serhii Kolisnyk ${ }^{1,2}$, Rostyslav Kravets ${ }^{1,2}$, Andrii Tsyhomskyy ${ }^{1,2}$, Yaroslav Liskov ${ }^{1,2}$, Viktoriia Kolisnyk ${ }^{2}$, Oleksandr Marchuk ${ }^{1}$

${ }^{1}$ Department of Medical Rehabilitation and Medical Social Expertize, National Pirogov Memorial Medical University, Vinnytsya, Ukraine, 21018

${ }^{2}$ Center of Medical Rehabilitation and Sports Medicine, Vinnytsya, Ukraine, 21018

\section{Introduction:}

PRM Physicians evaluate not only severity of lesions of functioning, activity and participation of patients, but also pathological changes at every organizational level of the organism.

There is no unified tool for entire assessment of pathological structural and functional disorders.

It is necessary to develop holistic approach for integration of knowledge and skills among physicians of different specialties in treatment and rehabilitation directions of medicine and introduce interdisciplinary multilevel system for diagnostics, treatment and rehabilitation. Multimorbidity and comorbidity are additional obstacles for successful performance of rehabilitation management that lead to reducing of cost and time effectiveness.

Purpose: To develop and research effectiveness of multi-level medical rehabilitation system for entire accurate detection of pathological structural and functional changes in all organizational levels of human organism.
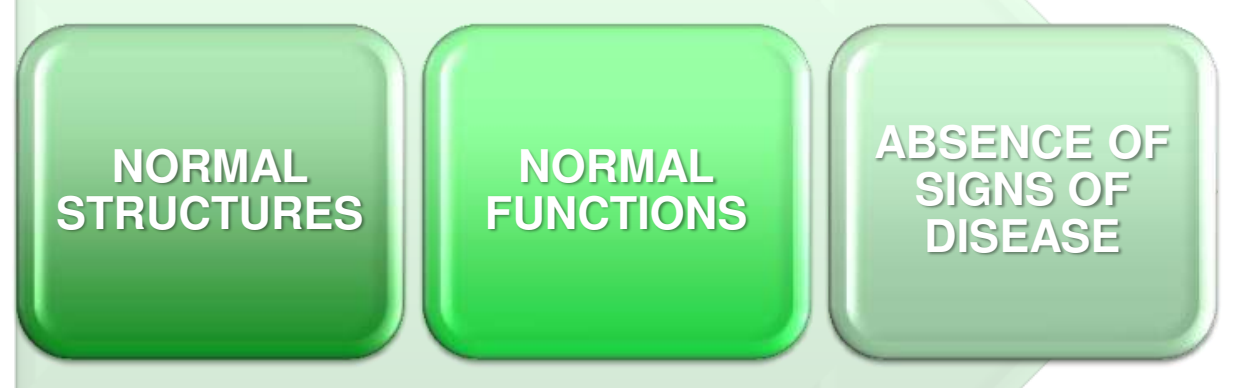

\section{Method:}

This is a fragment of open multicenter, controlled, prospective study of the effectiveness of multi-level medical rehabilitation approach in patients with diseases of internal organs and systems. Ultrasound, X-ray, CT, MRI, clinical investigations, functional and lab tests, multifactorial analysis were performed.

\section{Results:}

We introduce conception of multilevel medical system that implies of structural and functional interactions in somatic, system, organ, tissue, biochemistry, biophysics, informational levels of human organism.

Key structures and functions, diagnostics, treatment, rehabilitation, control of effectiveness are predicted in all aforementioned levels.

\begin{tabular}{|c|c|c|c|}
\hline LEVEL & $\begin{array}{l}\text { STRUC } \\
\text { TURES }\end{array}$ & $\begin{array}{l}\text { FUNCTI } \\
\text { ONS }\end{array}$ & SIGNS \\
\hline SOMATIC & $\begin{array}{l}\text { TREATME } \\
\text { NT }\end{array}$ & $\begin{array}{l}\text { REHABILIT } \\
\text { ATION }\end{array}$ & $\begin{array}{l}\text { DIAGNOSTI } \\
\text { CS }\end{array}$ \\
\hline SYSTEM & $\begin{array}{l}\text { TREATME } \\
\text { NT }\end{array}$ & $\begin{array}{l}\text { REHABILIT } \\
\text { ATION }\end{array}$ & $\begin{array}{l}\text { DIAGNOSTI } \\
\text { CS }\end{array}$ \\
\hline ORGAN & $\begin{array}{l}\text { TREATME } \\
\text { NT }\end{array}$ & $\begin{array}{l}\text { REHABILIT } \\
\text { ATION }\end{array}$ & $\begin{array}{l}\text { DIAGNOSTI } \\
\text { CS }\end{array}$ \\
\hline TISSUE & $\begin{array}{l}\text { TREATME } \\
\text { NT }\end{array}$ & $\begin{array}{l}\text { REHABILIT } \\
\text { ATION }\end{array}$ & $\begin{array}{l}\text { DIAGNOSTI } \\
\text { CS }\end{array}$ \\
\hline $\begin{array}{l}\text { BIOCHE } \\
\text { MISTRY }\end{array}$ & $\begin{array}{l}\text { TREATME } \\
\text { NT }\end{array}$ & $\begin{array}{l}\text { REHABILIT } \\
\text { ATION }\end{array}$ & $\begin{array}{l}\text { DIAGNOSTI } \\
\text { CS }\end{array}$ \\
\hline $\begin{array}{l}\text { BIOPHYS } \\
\text { ICS }\end{array}$ & $\begin{array}{l}\text { TREATME } \\
\text { NT }\end{array}$ & $\begin{array}{l}\text { REHABILIT } \\
\text { ATION }\end{array}$ & $\begin{array}{l}\text { DIAGNOSTI } \\
\text { CS }\end{array}$ \\
\hline $\begin{array}{l}\text { INFORMATI } \\
\text { ONAL- } \\
\text { ENERGETIC }\end{array}$ & $\begin{array}{l}\text { TREATME } \\
\text { NT }\end{array}$ & $\begin{array}{l}\text { REHABILIT } \\
\text { ATION }\end{array}$ & $\begin{array}{l}\text { DIAGNOSTI } \\
\text { CS }\end{array}$ \\
\hline
\end{tabular}

Somatic level was explored, main interleve interactions were elucidated. Form of the body, spine, joints, extremities are main structures in this level that perform integrating functions and responsible for the formation of somatotype, organs' syntopy. Due to ineffectiveness of pharmacology in somatic level, core treatment approaches are manual, orthopedic, surgical, instrumental correction of structural body changes Rehabilitation implies correction of dysfunctions by therapeutic exercises, diet, technical means etc.

\section{Conclusions:}

Further investigations are warranted for improving multilevel conception and integrating it into medical practice, education and management in rehabilitation.

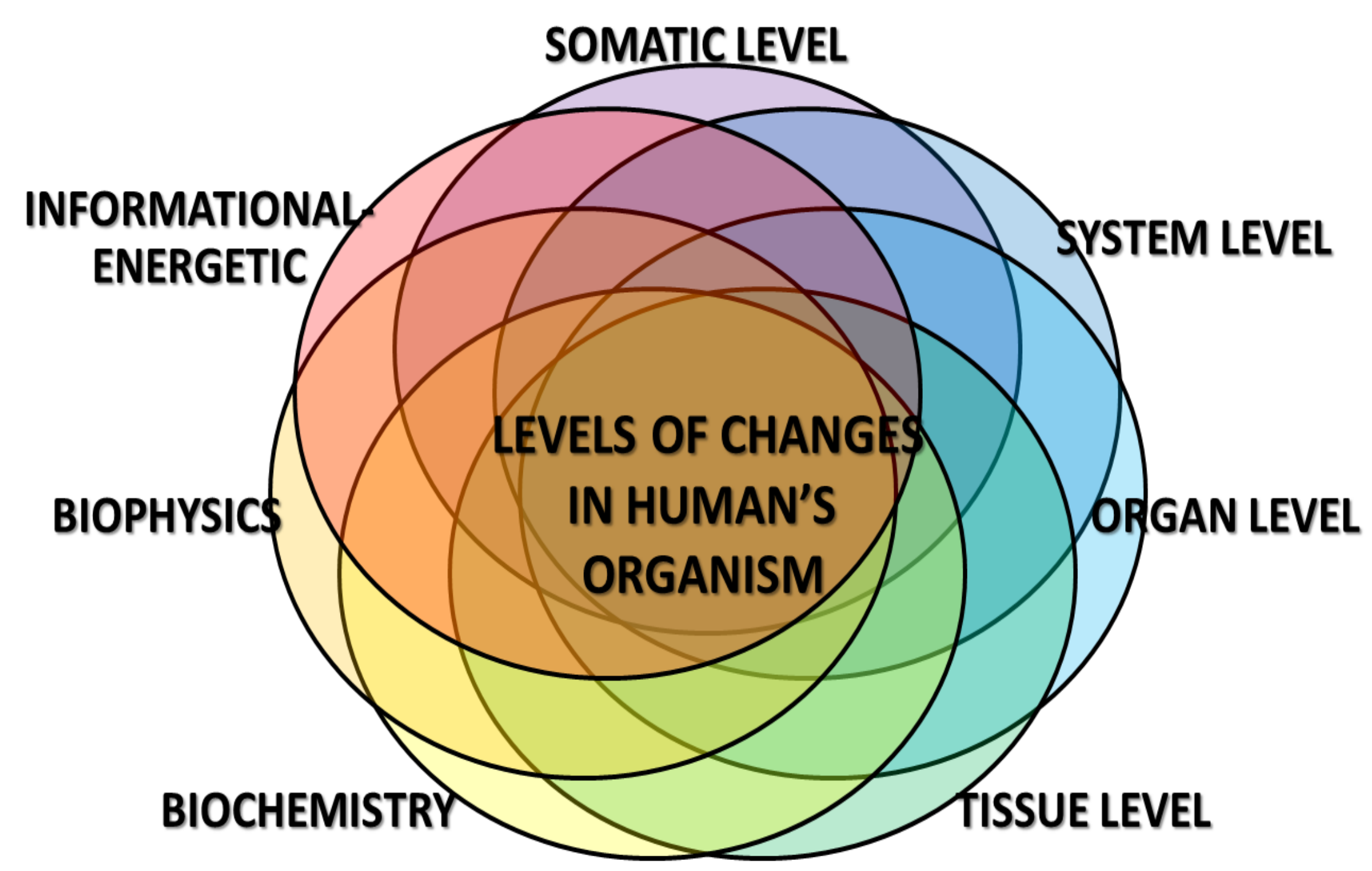

